An economic evaluation of photovoltaic grid connected systems (PVGCS) in Flanders for companies: a generic model.

Amaryllis Audenaert, Liesje De Boeck, Sven De Cleyn, Sebastien Lizin, JeanFrançois Adam

HUB RESEARCH PAPER 2010/16 JANUARI 2010

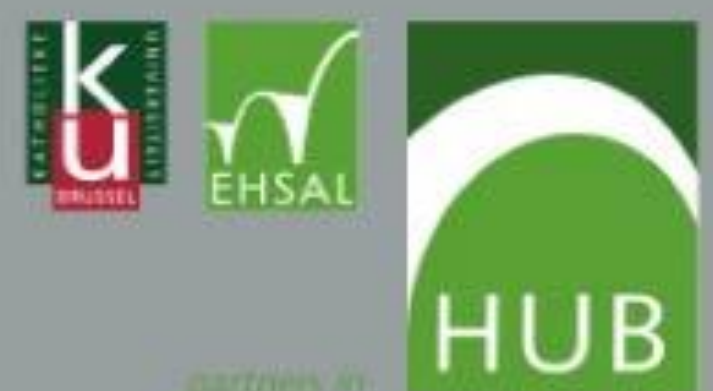




\title{
An economic evaluation of photovoltaic grid connected systems (PVGCS) in Flanders for companies: a generic model.
}

\author{
Amaryllis Audenaert1,2, Liesje De Boeck ${ }^{3,4}$, Sven De Cleyn², Sebastien Lizin5, Jean-François Adam ${ }^{6}$ \\ ${ }^{1}$ Artesis Hogeschool Antwerpen, Paardenmarkt 92, 2000 Antwerp, Belgium \\ Phone: +32 321379 33, Fax: +32 323186 70, E-mail: amaryllis.audenaert@artesis.be \\ ${ }^{2}$ Universiteit Antwerpen, Faculty of Applied Economics, Prinsstraat 13, 2000 Antwerp, Belgium \\ ${ }^{3}$ HUBrussel, Center for Modeling and Simulation, Stormstraat 2, 1000 Brussels, Belgium \\ Phone: +32 260982 72, Fax: +32 221764 64, E-mail: liesje.deboeck@ hubrussel.be \\ ${ }^{4}$ Affiliated Researcher Katholieke Universiteit Leuven, Faculty of Business and Economics, Research \\ Center for Operations Management, Naamsestraat 69, 3000 Leuven, Belgium \\ ${ }^{5}$ Student Ugent \\ ${ }^{6}$ Euroclear, Koning AlbertII-laan 1, 1210 Brussel
}

\begin{abstract}
In this paper an economic evaluation of photovoltaic grid connected systems (PVGCS) for companies situated in Flanders is conducted by using a generic Excel model. The model is unique in that it includes the dimension of taxation. This inclusion is required, otherwise the fiscal benefit of using solar panels is not accounted for. The model uses the cash flow projection method. This technique allows the calculation of the following classical evaluation criteria: net present value, internal rate of return, payback period, discounted payback period, profitability index, yield unit cost, yield unit revenue and breakeven turnkey cost. Their outcome makes it possible to answer the question whether installing a PVGCS in Flanders is a responsible financial investment for companies. Furthermore, the paper estimates whether the corporate environment is ready for a subsidy legislation change. This change has recently been announced and as such it is possible to gauge whether the current market situation is profitable given future legislation.
\end{abstract}

Keywords: PVGCS; Economic evaluation after taxes; Companies in Flanders; Future legislation sensitivity analysis.

\section{Introduction}

It has been proven for the UK that if all solar irradiation could be converted to a useful form of energy with an average efficiency of 5\%, only $3 \%$ of its land would suffice to supply its total electricity demand (Jackson \& Oliver, 2000). Integrating photovoltaic (PV) panels into existing building structures could even reduce this amount of land to 0 (Hill, O'Keefe, \& Snape, 1995). Moreover, PV installations are not subject to energy price fluctuations (Awerbuch, 1995), as the fuel they drive on is sunshine. Irradiation is for free and no one can be excluded from it. Therefore the PV technology has attracted increasing attention of policy makers because it is ought to be capable of delivering sustainable electricity (Jackson \& Oliver, 2000). Politicians promote solar energy as a relevant substitute for fossil fuels to move one step further towards reaching environmental goals such as the global Kyoto Protocol or the European 20-20-20 goals. Nevertheless, it should be noted that solar panels are not without any environmental impact. The production phase and the disposal of the 
modules at the end of their useful life cause the dispersion of greenhouse gasses (Alsema \& Nieuwlaar, 2000). Hence, from a governmental point of view, policies should not solely be based on solar module productivity. Indeed, this would imply running the risk of promoting PV technologies that are most threatening to the environment (Andersson \& Jacobsson, 2000). Such actions would jeopardise their initial sustainable objective.

The above mentioned benefits briefly highlight the potential of solar PV systems. Such installations can be divided into two technology types: photovoltaic stand alone and grid connected systems (Deutsche Gesellschaft für Sonnenenergie, 2005). In developed countries PVGCS are most often used because grids are readily available. Unlike stand alone systems, there is no need for batteries to store the produced electricity. Still technological advances, regulatory support and financial and economic criteria will play a major role in the further dissemination of PVGCS (Nofuentes, Aguilera, \& Muñoz, 2002). According to the literature, classical evaluation methods are not capable of grasping the real value of PV installations. On one hand, they do not account for externalities (Menegaki, 2008), financial risk, portfolio costs and strategic and managerial options (Awerbuch, 2000). On the other hand, they focus exclusively on direct costs, ignore the concept of cost of quality and only account for current technology costs. As such they tend to favour older fossil fuel driven techniques (Awerbuch, 2000). For example, it has been calculated that the value of solar electricity compared to coal is underestimated by $\$ 0.02-0.05 / \mathrm{kWh}$ without taking external costs into account (Awerbuch, 1995). Consequently, if acceptable results are obtained for PV systems using these traditional methods, one can be sure of the investment's viability. Still the question should be asked as to why classical economic evaluation methods are used instead of methods that take the limitations mentioned above into account? The reason is threefold: they allow a more timely evaluation (Menegaki, 2008), energy planners are comfortable working with them (Awerbuch, 2000) and external costs are not of direct importance to the consumer.

This paper aims to provide an answer to the following research question: Is installing a PVGCS in Flanders a responsible financial investment for companies? We will provide an adequate answer to this question by using a generic economic evaluation model. This model has been put into practise by creating an Excel file with matching formulas. Results were obtained by means of a generic case study making it exemplary for large Flemish companies. Furthermore, we have performed a sensitivity analysis on the most influential parameters and simultaneously on the impact of the announced green current legislation change.

Related contributions can be found in Bernal-Agustín \& Dufo-López (2006), Chabot (1998), Caamaño \& Lorenzo (1998) and Nofuentes, Aguilera \& Muñoz (2002). Bernal-Agustín \& Dufo-López (2006) performed an economical analysis of PVGCS in Spain. Chabot (1998) put forward a global economic analyzing methodology that allows simplifying the cost and the profitability assessment of PV systems. Caamaño \& Lorenzo (1998) presented an analytical model to estimate economic performances of PVGCS in non-ideal situations. Nofuentes, Aguilera \& Muñoz (2006) gave a short introduction of financial tools to evaluate PVGCS. In this paper we focus on PVGCS for companies based in Flanders, a study that is non-existing up to now. Location is an important factor in a PV investment evaluation. Productivity and subsidy legislation are parameters dependent of the political and geographical location. Furthermore, the modelling of Belgian and Flemish subsidy legislation demands a substantial new approach. In other countries or regions feed-in tariffs are installed to promote solar electricity. In Flanders this is not the case. Here companies benefit from the Flemish green current certificates, the Flemish ecology subsidy and the Federal elevated investment deduction. 
The latter requires the inclusion of taxes into the model; otherwise this tax benefit is unaccounted for. Neither general investment literature nor the above mentioned specific PV investment literature guides our way.

The remainder of this paper is divided into the following three sections: Methodology, Economic evaluation and Conclusion. The first section familiarizes the reader with PVGCS terminology, dissects the build-up of the generic economic evaluation model and elaborates on the financial evaluation criteria that can be drawn from it. The second section answers this articles' main question by applying the model to a case study. Also, by performing a sensitivity analysis the impact of a green current legislation change is checked. The final section summarizes the major findings, draws attention to the limits of this model and points out possibilities for further research.

\section{Grid Connected Photovoltaic Systems in Flanders}

Grid connected systems can be divided into two categories being systems directly connected to the public grid and systems connected to the public grid via the in-house grid (Deutsche Gesellschaft für Sonnenenergie, 2005). For PVGCS producing more than $10 \mathrm{~kW}$ a separate green current meter is installed by the company's grid connector and the incoming and outgoing electricity have to be measured separately. (Vlaamse Reguleringsinstantie voor de Elektriciteits- en Gasmarkt) The constitution of a PVGCS in Flanders for an installation making more than $10 \mathrm{~kW}$ is depicted in figure 1. We will be taking the assumption in this paper that companies belong to the in-house grid category producing more than $10 \mathrm{~kW}$. The Flemish situation differs from that in other regions or countries because of the presence of a green current meter. This device plays an important role in the acknowledgement of "green current certificates" which can be sold for a legally fixed minimum price to the company's grid connector.

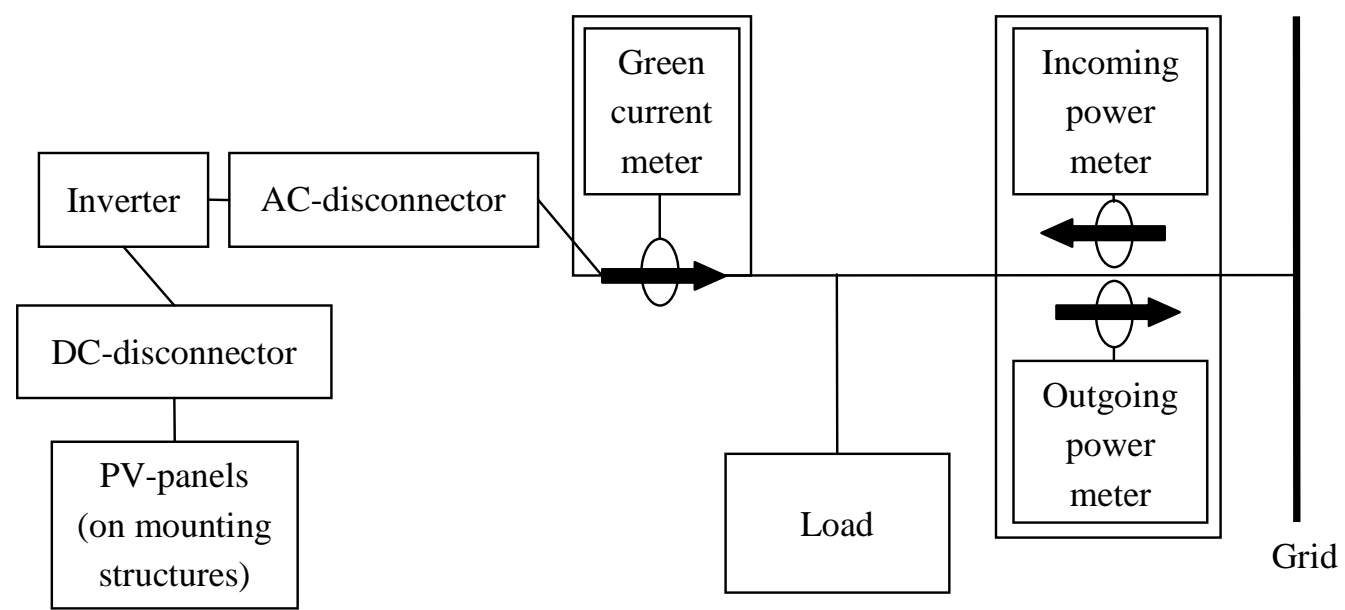

Figure 1: PVGCS in Flanders for companies

To be able to understand the financial impact of PVGCS, one has to be familiar with its main components and their basic functioning. A PVGCS generally consists of the following main components: PV panels, mounting structure, inverter, alternating current (AC) and direct current (DC) cabling, AC and DC switch disconnectors and energy meters. To revise its functioning we refer to Deutsche Gesellschaft für Sonnenenergie (2005). If more power is produced than required by the 
company, the remaining electricity is inserted in the public grid after being monitored by an outgoing power meter. If insufficient power is produced, extra electricity is drawn from the public grid and measured by an incoming power meter. The latter situation is the expected scenario. It seems to be clear that solar electricity is not suited for covering companies' electricity needs at all times. Still it supports absorbing peaks in electricity demand and reducing electricity costs. (Deb Mondol, Yohanis, \& Norton, 2009) It also provides protection from energy price fluctuations and reflects a green image upon the company.

\section{Methodology}

Knowing the crucial components and subsidy legislation, it is possible to search for a qualified economic evaluation method. Literature indicates that in order to carry out a complete evaluation a cost-benefit analysis has to be executed (Menegaki, 2008). This implies dealing with all limitations mentioned in section 1. For known reasons (see supra: section 1) we have chosen not to do so. Also remark that our model does not serve PV array optimisation purposes. Our main goal is to develop a generic economic evaluation model. General investment analysis literature recommends the use of the cash flow projection method (Dorsman, Vanthienen, Keuleneer, Van Hulle, \& Gheysens, 2000). Comparison of general investment literature to PV investment literature indicates only one difference, i.e. the inclusion of financing costs in the cash flow projection for a PV evaluation (Bernal-Agustín \& Dufo-López, 2006). Accordingly if lending were an option for a company, yearly interest costs are implemented into the model whereas the capital repayment is discarded. Indeed, when performing an investment analysis a negative cash flow at the beginning of the project is preferred.

A cash flow projection allows us to calculate the following (classical) financial evaluation criteria: net present value (NPV), internal rate of return (IRR), payback period (PBP), discounted payback period (DPBP), profitability index (PI), yield unit cost (YUC), yield unit revenue (YUR) and break even turnkey cost (BTC). Bear in mind that all criteria will be calculated using the resulting total cash flow which takes taxes into consideration (see infra: section 2.1). Furthermore by conducting a sensitivity analysis, we can determine the influence of the major drivers in the obtained values for those financial criteria. It should be noted that the model is deterministic, it operates through fixed parameters. No distribution was found in the literature concerning malfunctioning parts or other events that can be attributed to chance. Additionally, the resulting charts are submitted to further analysis to find out general trends and the impact of future legislation. We were inspired to do so by Chabot (1998) and Bernal-Agustín \& Dufo-López (2006). 


\subsection{Build-up of the generic economic evaluation model}

In what follows, we dissect the build-up of the generic model. According to the literature a cash flow can be projected by means of the following components: costs, revenues and taxes. It should also be noted that the subscript $i$ represents the year and that the investment takes place in year 0 .

\subsubsection{Costs}

\begin{tabular}{|c|c|c|}
\hline $\mathrm{Nr}$ & Cost & Equation \\
\hline 1 & $\begin{array}{l}\text { Initial } \\
\text { investment } \\
\text { costs }\left(l_{0}\right)\end{array}$ & $I_{0}=p \times N p_{\max } \Pi$ \\
\hline 2 & $\begin{array}{l}\text { PVGCS price } \\
\text { components } \\
\text { percentages }\end{array}$ & $100 \%=\alpha_{\text {panel }}+\beta_{\text {gtructure }}+\gamma_{\text {inverter }}+\delta_{\text {placiment }}+\theta_{\text {oabling and otherg }}$ \\
\hline 3 & $\begin{array}{l}\text { Operating and } \\
\text { maintenance } \\
(\mathrm{O} \& \mathrm{M}) \text { costs }\end{array}$ & $C_{\text {OaM }, i}=C_{\text {panel } h_{i} i}+C_{\text {invertor }, i}+C_{\text {oleaning }, i}$ \\
\hline 4 & $\begin{array}{l}\text { Financing } \\
\text { costs }\end{array}$ & $C_{\text {financing }, i}=r \times D_{i}$ \\
\hline 5 & insurance costs & $C_{\text {insumaneei }}$ \\
\hline 6 & $\begin{array}{l}\text { Yearly total } \\
\text { cost }\end{array}$ & $C_{i}=C_{\text {og } N_{n} i}+C_{\text {finaneing } i}+C_{\text {insuraneg }, i}$ \\
\hline
\end{tabular}

To express the generic nature of our model, the total initial investment is expressed as the product of the number of Wattpeaks ( $W p_{\max }$ ) maximally produced by the PVGCS at the beginning of its lifetime and its all inclusive price per $\mathrm{Wp}(\mathrm{p})$. This is indicated by equation 1 . The all inclusive price incorporates the cost of purchasing all components (see supra: section 2), the installation cost and the cost of a feasibility study if applicable.

For legislative reasons it is important to know which part of the total initial investment that can be attributed to the essential PVGCS components (see infra: equation 9). However, all initial investment cost components are the price of the photovoltaic panels $\left(\alpha_{p a n e l}\right)$, the mounting structure $\left(\rho_{\text {stmoture }}\right)$, the inverters $\left(\gamma_{\text {inumertar }}\right)$, the placement of the system $\left(\delta_{\text {placoment }}\right)$, the cabling and

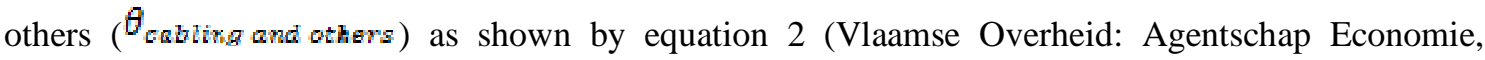
2007).

The O\&M costs for a PVGCS can be obtained by summation of the following costs: the replacement cost of malfunctioning panels $\left(C_{\text {paneli } i}\right)$, the replacement cost of inverters $\left(C_{\text {invertor,i }}\right)$, the maintenance cost of the PVGCS ( $\mathcal{C}_{\text {oleaning, } i) \text {. }}$

No data could be found about the specific time occurrence of panel malfunctions. Consequently, we assume this to be an annual cost except during the first 2 years due to product warranty. Moreover technology costs are expected to drop in the short term thanks to mass production (Gabler, 2001). 
However, we assume in the longer term of 20 years prices will rise again for old technology which does not benefit mass production anymore. Consequently no price change has been taken into account. On average an inverter needs replacement, because it malfunctions or breaks down, in the midlife of the PV-system (Yun Seng, Lalchand, \& Mak Sow Lin, 2008). PV panels have an expected lifetime between 25-30 years (Alsema \& Nieuwlaar, 2000), subsequently the midlife age is set at 15 years.

The maintenance cost is the yearly cost of cleaning the solar panels and other small maintenance jobs such as replacing cabling or performance check-ups. The cost is determined by the price and the quantity of man hours attributed to it. Our research does not provide us with a specific guideline for modelling maintenance costs defined as we have. It does however indicate that maintenance costs in general are very low (Zahedi, 2009).

The investment may require borrowing money. Therefore the option of lending any amount between 0 and the total initial investment has been included. The financing costs consist of annual payments of interest. These amounts are dependent on the charged interest rate (r) and the way the loan is decided to be repaid. The model assumes the investor has opted for fixed annuities. This means that the interest has to be paid on the remaining debt $\left(D_{i}\right)$ of the borrowed amount.

To protect the investment effort from damages caused by unforeseen circumstances such as storms, hail, fire and lightning an insurance can be applied for. The insurance costs are the annual insurance premiums that have to be paid.

\subsubsection{Revenues}

\begin{tabular}{|c|c|c|}
\hline $\mathrm{Nr}$ & Revenue & Equation \\
\hline 7 & $\begin{array}{l}\text { Saved energy } \\
\text { expenses }\end{array}$ & $R_{\text {energyi }}=P_{\text {energyi }} \times E_{i}$ \\
\hline 8 & $\begin{array}{l}\text { Elevated } \\
\text { investment } \\
\text { deduction }\end{array}$ & $S_{\text {investment, } 1}=\omega_{\text {muegtment }} \times I_{0}$ \\
\hline 9 & $\begin{array}{l}\text { Green current } \\
\text { certificates' } \\
\text { revenue }\end{array}$ & $R_{\text {Green current certificates, }}=S_{\text {Green current certificates }} \times E_{i}$ \\
\hline 10 & Ecology subsidy & $S_{\text {acology } 0}=\left(\alpha_{\text {panel }}+\gamma_{\text {iwverter }}+\theta_{\text {eablingand athers }}\right) \times I_{0} \times \sigma_{\text {geology }}$ \\
\hline 11 & $\begin{array}{l}\text { Yearly total } \\
\text { revenues }\end{array}$ & $R_{i}=R_{\text {ensrgy,i }}+R_{\text {Green current centificateg,i }}+S_{\text {guology, } i}$ \\
\hline
\end{tabular}

Saved energy expenses can be calculated by multiplying the energy price $\left(\boldsymbol{P}_{\text {energy, }}{ }^{i}\right)$ in $€ / \mathrm{kWh}$ and the amount of energy the PVGCS produces each year $\left(F_{i}\right)$ in $\mathrm{kWh}$, see Equation 7.

The model consequently assumes that all produced electricity is consumed by its producer and not fed back into the grid (see supra: section 2). Furthermore, a constant rise in energy prices each year has been built in. The amount of energy produced is guaranteed by most producers to be no lower than $90 \%$ after 10 years and $80 \%$ after 20 years of the initial maximally produced Wp. Accordingly a decrease of electricity production by $1 \%$ per year has been simulated. This is allowed because the conversion of $\mathrm{Wp}$ to $\mathrm{kWh}$ is linear. This method can be considered rather conservative as some producers guarantee the same productivity over a longer period of time. The conversion rate, however, depends of all factors that influence the productivity of PVGCS. The most important factors are the amount of irradiation, the orientation and inclination of the panels and the inverter (Deutsche 
Gesellschaft für Sonnenenergie, 2005). For optimal circumstances in Flanders a conversion rate between 0.80 and $0.85 \mathrm{kWh} / \mathrm{Wp}$.year (Ecostream, 2006) is obtained.

To support the dissemination of solar technology policy makers grant subsidies. However a variety of supporting measures has been put into effect across the world (Jackson \& Oliver, 2000). Incentives differ when comparing countries, even regions (Zahedi, 2009). In Belgium subsidies for Flemish companies exist at two levels: the Federal level and the Flemish region.

The Federal government offers a tax incentive, called the "elevated investment deduction" $\left(S_{\text {mvestment, } 1}\right)$, to persuade companies to invest in solar technology. The deduction amounts to a single benefit of a determined percentage ( $\omega_{\text {imnastmems }}$ ) of the total initial investment costs that can be subtracted from taxable profits (Vlaams Energieagentschap, 2007). Its obtainment thus implies that the company is profitable in that fiscal year. Furthermore, actual cash savings take place a year after tax forms have to be handed in. The deduction is calculated as in Equation 8. Hence the model accounts for direct differential cash flows, taxes included.

On regional level two supporting measures can be found. Firstly, the Flemish authorities have put forth a legislation framework that provides a minimum price of $45 \mathrm{c} / \mathrm{kWh}$ for produced "green current" ( $S_{\text {Green ourrent certificates }}$ ). If used to full advantage this results in a productivity dependent revenue

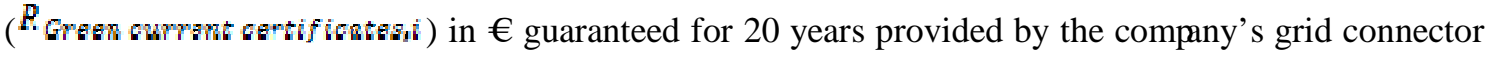
(Vlaamse Reguleringsinstantie voor de Elektriciteits- en Gasmarkt). Equation 9 shows the computational method.

Secondly, companies can also request the Flemish region for financial support from "the ecology subsidy" ( $\left.S_{\text {ecologyo }}\right)$. If granted, this accounts for a certain percentage $\left(\sigma_{\text {ecoiggy }}\right)$ of the value on the essential parts of the PVGCS. The subsidy can only be accorded once and we assume it is paid out completely during the year of investment (Vlaamse Overheid: Agentschap Economie, 2007). The subsidy is computed as indicated in Equation 10.

To revise legislation and its resulting terms that have to be fulfilled in order to be granted these subsidies, we refer to the website of the Flemish Energy Agency (VEA).

\subsubsection{Corporate taxes $\left(T_{1} i\right)$}

The elevated investment deduction acts as a tax benefit. Therefore it is necessary to include corporate taxes into the model. But by doing so, we enter uncharted territory. Indeed, no literature has been found that models cash flows after taxes. Corporate taxes are equal to the corporate tax percentage $(\partial)$ multiplied with the corporate results as represented in Equation 12.

$$
\begin{array}{ll}
T_{i}=\partial \times\left(R_{i}-C_{i}-A_{i}-S_{\text {investment, }}\right) & \text { if } i=1 \\
T_{i}=\partial \times\left(R_{i}-C_{i}-A_{i}\right) & \text { if } i \neq 1
\end{array}
$$

Corporate results depend on the way the investment will be amortized. We have chosen degressive amortization $\left(A_{i i}\right)$ because fiscally this is the most favourable. Amortizations are brought into the results starting the year after the investment is completed. No legislation exists on how fast a PVGCS should be amortized (Derycke, 2007). Normally corporate taxes are to be paid only if total corporate results are positive. However, a generic differential analysis can only show how much taxes will rise or fall by executing the project. 


\subsubsection{Cash flows $\left(\mathrm{CF}_{i}\right)$}

Cash flows after taxes result from the subtraction of yearly total costs, initial investment and taxes from the revenues (Gitman, 2003). It should be noted that financing costs have been considered as cash costs. This is justified because the model not only aims to be an investment analysis but intends to be a complete evaluation of PVGCS located in Flanders (Dorsman, Vanthienen, Keuleneer, Van Hulle, \& Gheysens, 2000). Equation 13 represents our approach.

$$
\begin{aligned}
C F_{i} & =R_{i}-T_{i}-C_{i}-I_{i} & \text { if } i & =0 \\
C F_{i} & =R_{i}-T_{i}-C_{i} & \text { lif } l & >0
\end{aligned}
$$

\subsection{Financial evaluation criteria}

The financial evaluation criteria should allow formulating an answer to the main question: is installing a PVGCS in Flanders a responsible financial investment for companies? This question can be

\begin{tabular}{|c|c|c|}
\hline $\mathrm{Nr}$ & $\begin{array}{l}\text { Evaluation } \\
\text { criteria }\end{array}$ & Equation \\
\hline 14 & $\begin{array}{l}\text { Net } \quad \text { Present } \\
\text { Value }\end{array}$ & $\left.N P V=\sum_{i=0}^{19} \mathrm{I}\left(\frac{C F_{i}-R_{\text {ewergy, } i}}{\left(1+d^{\prime}\right)^{i}}\right]+\frac{R_{\text {energy, } i}}{(1+d)^{i}}\right)$ \\
\hline 15 & $\begin{array}{l}\text { Internal Rate of } \\
\text { Return }\end{array}$ & $0=\sum_{i=0}^{19} \frac{C F_{i}}{(1+I R R)^{i}}$ \\
\hline 16 & $\begin{array}{l}\text { Profitability } \\
\text { Index }\end{array}$ & $P I=\frac{N P V}{I_{0}}$ \\
\hline 17 & Pay Back Period & $\sum_{i=0}^{P E P} \mathrm{CH} F_{i}=0$ \\
\hline 18 & $\begin{array}{l}\text { Discounted Pay } \\
\text { Back Period }\end{array}$ & $\sum_{i=0}^{D F E P}\left(\frac{C F_{i}-A_{\text {tnarghi }}}{\left(1+d^{\prime}\right)^{i}}+\frac{R_{\text {tnargy } i}}{(1+d)^{i}}\right)=0$ \\
\hline 19 & Yield Unit Cost & $Y U C=\frac{I_{0}+\sum_{i=0}^{1 y} \frac{C_{i}}{\left(1+d^{\prime}\right)^{i}}}{\sum_{i=0}^{19} E_{i}}$ \\
\hline 20 & $\begin{array}{ll}\text { Yield Unit } \\
\text { Revenue }\end{array}$ & $Y U R=\frac{\sum_{i=0}^{19} \frac{R_{i}}{\left(1+d^{7}\right)^{l}}}{\sum_{i=0}^{19} E_{i}}$ \\
\hline 21 & $\begin{array}{l}\text { Breakeven } \\
\text { Turnkey Cost }\end{array}$ & 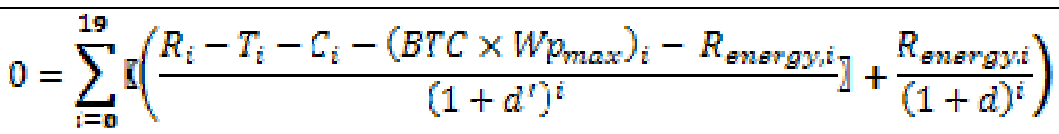 \\
\hline
\end{tabular}
answered by applying multiple financial criteria to our model.

The main question every company should answer is whether the asset's benefits will outweigh the costs over time. Time and accordingly the time value of money plays an important role. Hence the need for the company's discount rate, i.e. the rate that represents the opportunity cost of investing the money in an asset with similar risk. Adjusting this rate for inflation renders the adjusted discount rate 
$\left(d^{\prime}\right)$. We have applied this rate to all components of cash flow, except for the saved energy expenses. These savings are discounted using the normal discount rate $(d)$, because we already accounted for energy price inflation. Furthermore, we have chosen a time span of twenty years, because this matches the number of years the company can cash in the minimum green current subsidy. The NPV is calculated as follows:

If NPV is greater than or equal to 0 the investment is worth being considered. Furthermore, the NPV method allows ranking of alternative investments. On the other hand -and although it is included- the value of the NPV does not indicate the initial investment outlay (see supra: equation 17). Consequently choosing solely based on NPV value between two NPV equal projects is impossible.

NPV is dependent on the chosen discount rate and thus of the company under revision. The IRR however is not. It determines the discount rate for the project to be break even over a period of 20 years not taking inflation into account. Hence it is a generic measure that allows comparison with the company specific discount rate. If the company specific discount rate is smaller than the IRR, then the project is value-adding. The IRR is determined according to the formula:

PI relates the NPV to the initial investment outlay. This is important because it allows differentiation between NPV equal projects. Companies will prefer the project with the smallest initial investment and thus the project having the highest PI. A PI greater than 1 is considered as being beneficial (Van Campenhout, 2008).

Where IRR is a percentage, the PBP is the actual time needed for the initial investment to be recuperated completely (equation 17). In other words it is the number of years needed to reach a positive cumulative undiscounted cash flow. Taking the time value of money into account requires calculating the DPBP (equation 18). This is the number of years needed to reach a positive cumulative discounted cash flow. Subsequently PBP, unlike DPBP, isn't company specific but doesn't take the time value of money into account.

The YUC represents the average discounted price per kWh for a company making its own electricity over a period of twenty years. Equation 19 indicates its computation. The YUC is the average discounted revenue per $\mathrm{kWh}$ for a company making its own electricity over a period of twenty years. Equation 20 shows the formula. It is useful, yet premature, to weigh the YUC against the price of buying electricity from a supplier versus the amount of subsidy you receive. If the price of autonomous electricity production is lower than buying electricity from a supplier, it is beneficiary. If not, the idea need not to be abandoned as long as the subsidy you receive is higher than the price of producing your own electricity. In other words this measure determines whether PVGCS are intrinsically profitable or profitable because of governmental subsidies that support them. However if one wishes to compare costs and revenues over a longer period of time, taking the time value of money into consideration, it is best done using YUR and YUC.

The BTC determines the maximum price per Wp that a company is willing to pay for a PVGCS having certain characteristics. This is useful in comparing offers. If the offering price per $\mathrm{Wp}$ is lower than the BTC, the supplier qualifies. The BTC therefore represents a supplier selection measure. It is calculated using the Excel-solver represented by equation 21 . 


\section{Economic evaluation}

\subsection{Generic case study: introduction}

The economical evaluation has been conducted for an optimally functioning PVGCS located on a horizontal surface in Flanders. This calls for an installation with southward orientation, an inclination of $35^{\circ}$, the absence of shading and optimally chosen decentralised inverters with matching string size. In such conditions $1 \mathrm{Wp}$ is assumed to provide about $0.825 \mathrm{kWh}$ the first year. Determining a universal all-inclusive price per $\mathrm{Wp}$ is impossible. This price depends on the following factors: the size of the order, the supplier with whom you place the order, the services they offer and last but definitely not least all the necessary components. The model uses the price of $3.95 € / \mathrm{Wp}$, which was obtained after demanding a real offering for installing 3,000,000 $\mathrm{Wp}$ of an average polycrystalline solar module. This necessitates about $28,266 \mathrm{~m}^{2}$ of panel surface, which is not equal to the total required surface. The surface will be even bigger taking shading constraints into consideration, making this case study exemplary for large companies. Hence the ecology subsidy amounts to a percentage of $6 \%$ on essential parts or a maximum of 1,750,000€, which are the numbers that were introduced in 2009 for large companies (Ondernemend Vlaanderen, 2009).

The evaluation stretches over a time period of 20 years, because this equals the timeframe of the actual green current subsidy legislation. In this case study we assume that the company decides to take on a loan to cover the entire initial investment outlay subtracted with the single subsidies and the situation in which it finances the project with private equity. By doing so it is possible to contrast the two ends of their investment spectrum. Furthermore, our model gives more realistic estimates compared to the rosy and simplistic calculations most suppliers provide their customers with. These calculations are inaccurate since a higher energy inflation rate is used and the system performance does not deteriorate. They are simplistic since the time value of money and the cost of replacing inverters is not taken into consideration. On the contrary, the assumption of paying for the system entirely autonomously is made frequently by dealers and thus financing costs are omitted. For the remaining parameters defined in our economical evaluation of a PVGCS see appendix 1.

This model is generic because most of the parameters can be applied to all large companies. For example: the yearly system performance deterioration rate, the corporate tax rate, the value of green current certificates, the ecology subsidy, and the elevated investment deduction are suited for that group. The remaining parameters on the other hand are realistic numbers for large companies. 


\subsection{Generic case study: results}

Implementing the case mentioned above in the generic model leads to the following results:

Table 2:

Results case study

\begin{tabular}{lrr}
\hline \multicolumn{1}{c}{ Measures } & \multicolumn{1}{c}{ Without loan } & \multicolumn{1}{c}{ With 100\% loan } \\
\hline Initial Investment & $\mathbf{1 1 , 8 5 0 , 0 0 0} €$ & $\mathbf{1 1 , 8 5 0 , 0 0 0} €$ \\
\hline Loan & $0 €$ & $10,666,185 €$ \\
Single subsidies & $1,183,815 €$ & $1,183,815 €$ \\
Payback Period (PBP) & 8.27 years & 10.21 years \\
Discounted Payback Period (DPBP) & $>50$ years & $>50$ years \\
Internal Rate of Return (IRR) & $9.13 \%$ & $6.53 \%$ \\
Net Present Value (NPV) & $-730,069.03 €$ & $-2,221,417.78 €$ \\
Profitability Index (PI) & -0.06161 & -0.18746 \\
Yield Unit Cost (YUC) & $0.28 € / \mathrm{kWh}$ & $0.33 € / \mathrm{kWh}$ \\
Breakeven Turnkey Cost (BTC) & $3.61 € / \mathrm{Wp}$ & $3.07 € / \mathrm{Wp}$ \\
\hline
\end{tabular}

Using the discounting method, the model enables us to state that it is economically responsible to initiate a PVGCS project. Considering that the discounting method is disadvantageous to the case of solar power, it adds evidentiary support to the result. As a matter of fact both internal rates of return over a lifespan of twenty years are positive. Comparing results indicates the importance of financing costs. Consequently, it is fair to conclude that these are costs that should not be omitted in an evaluation exercise. The charts 1 and 2 illustrate the effect of financing costs.

On top of this a comparison between the actual green current subsidy level, a 35 and 9 eurocent scenario has been executed. These are the subsidy levels that will be applied in 2010 and 2018 respectively for the duration of 20 and 15 years (Crevits, 2009). In the 9 eurocent scenario the formulas are analogous except for the duration numbers. Hence the analysis is carried out using current market data to check profitability in the context of future legislation. By means of NPV and IRR it is justifiable to say that given the current environment the installation of a PVGCS will not be profitable no matter what the financing cost are, keeping all other parameters fixed for the $9 \mathrm{c}$ scenario.

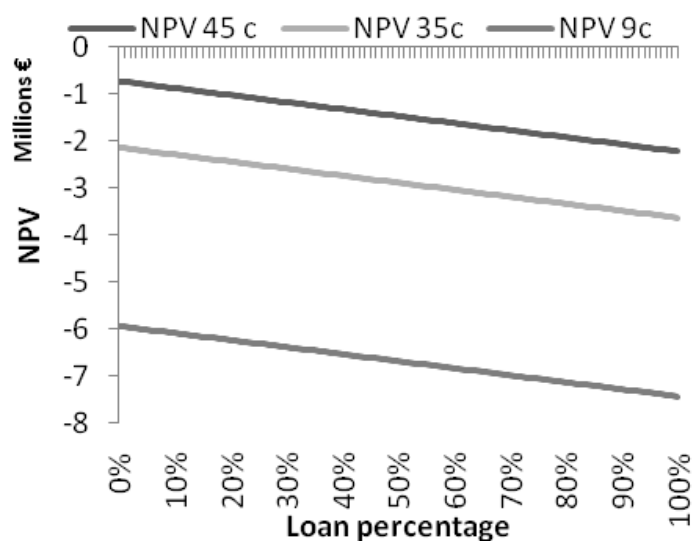

Chart 1: NPV investment spectrum

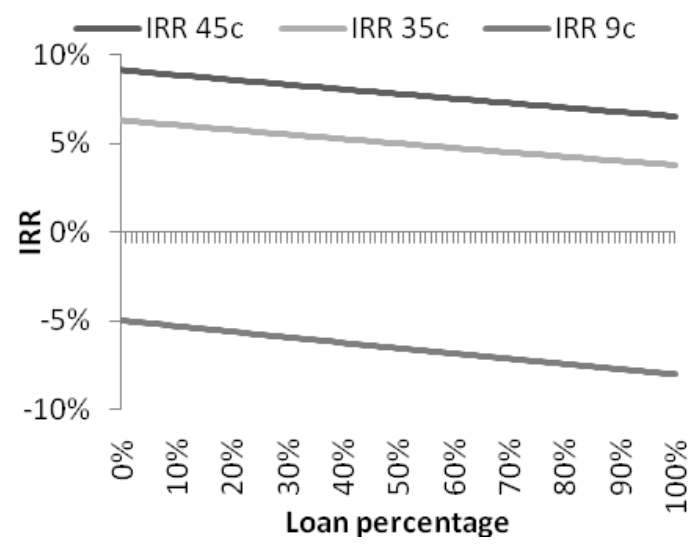

Chart 2: IRR investment spectrum 


\subsection{Sensitivity analysis}

To draw general conclusions a sensitivity analysis is performed using the 3 most influential variables: the initial investment cost, the discount rate and the electricity price. These were retrieved by applying various permutations and combinations to the data of the model. The analysis has been made using the figures of the $100 \%$ loan scenario, which is an acceptable assumption for a non-core business investment.

The graphs 3, 4, 5 and 6 show the influence of a price change on five financial criteria, for the three levels of subsidies mentioned previously. The first two measures are the NPV and the IRR. In general it is clear that NPV and IRR drop as the all-inclusive price rises. It is worth noting that the highest green current certificates are needed to persuade companies to invest in a PVGCS. Bear in mind that current average initial investment costs lay in an interval between 3.5 and $4.5 € / \mathrm{Wp}$ for companies (Luyckx, 2008).

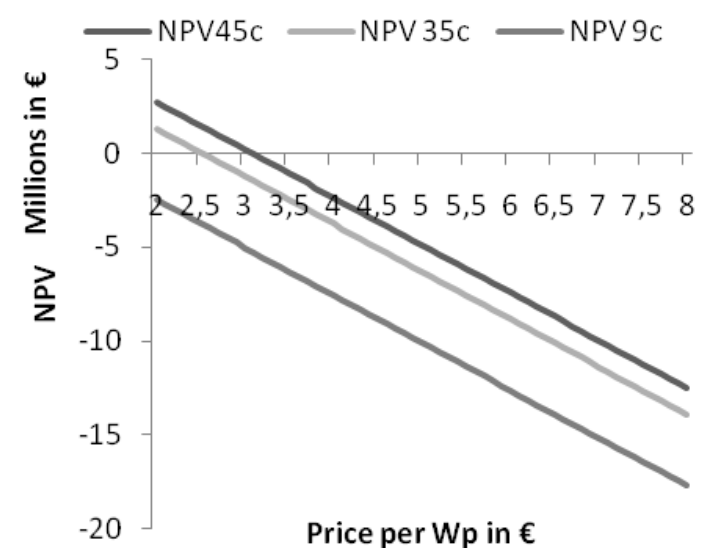

Chart 3: NPV price spectrum

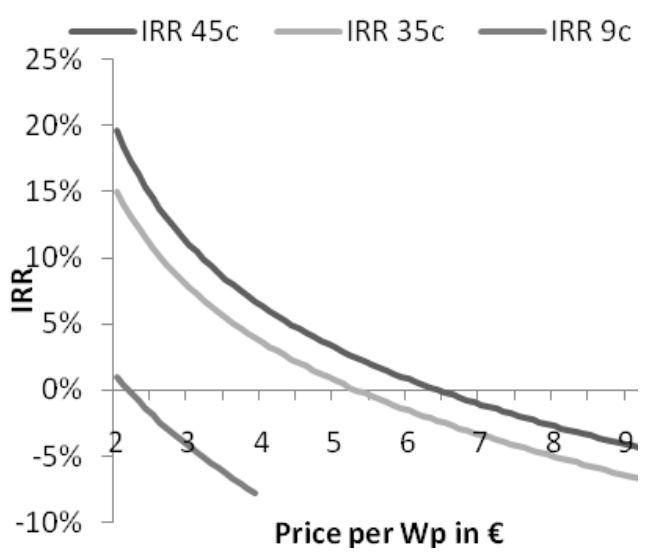

Chart 4: IRR price spectrum

The third displayable financial criterion is the PBP (Chart 5). As expected, the more a company has to pay, the longer the PBP. Considering the mentioned average price interval under current legislation the PBP lies between 9 and 11.7 years. If the subsidies are to drop to 35c the PBP increases and lies between 11 and 16.2 years.

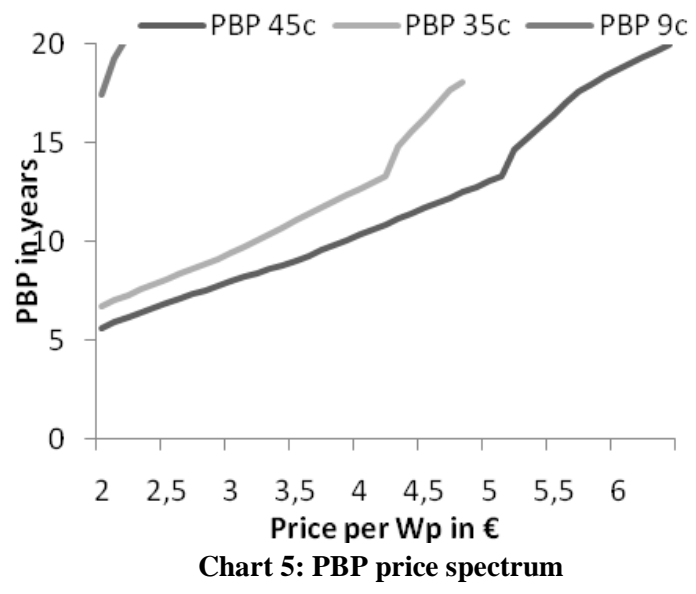


Once again it confirms that the highest green current subsidies are required to reach a desired PBP of less than 10 years. One might also notice the oddities in the curves. However they can be explained by the replacement of the inverters after 15 years. The Y-axis doesn't go higher than 20 years because this matches the period of time that green current certificates have a fixed price.

The final measures are the YUC ( $€ / \mathrm{kWh})$ and the YUR ( $€ / \mathrm{kWh})$. The YUR does not vary with the initial investment cost, however it does vary with green current subsidy level. The YUC displays the opposite behaviour. These measures are important because the intersects point out where the operational break even prices (per Wp), i.e. the prices excluding the elevated tax deduction, are situated. The 9 eurocent YUR does not have a crossing. It lies below all yield unit costs. It indicates that prices should plummet to a level below 2 euro per Wp. Additionally it is significant to notice that the yield unit cost is higher than the price of buying electricity made by using non renewable resources from a supplier.

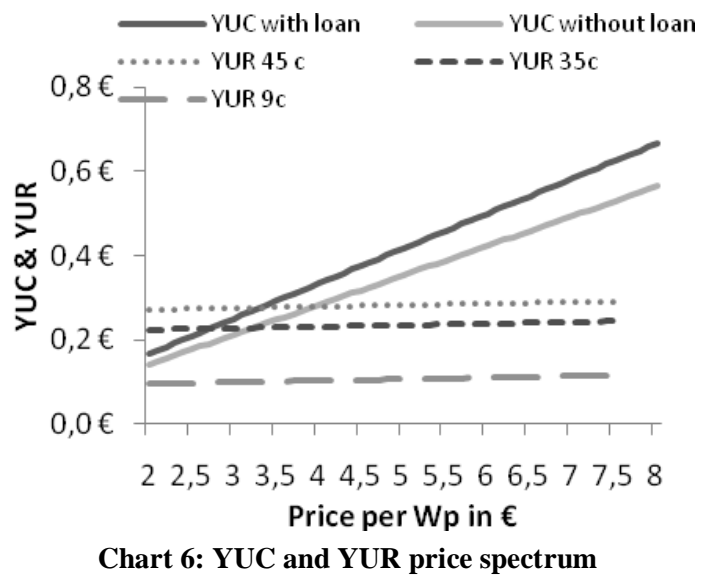

Graph 7 shows the effect of a discount rate change. The general trend is clear: the higher the discount rate, the lower the NPV. Former results were calculated with a $12 \%$ discount rate. Chart 7 shows the extent to which companies can expect a return on the PVGCS investment. Knowing that companies demand up to more than $10 \%$ return, it is fair to say that given current legislation and market prices not many will be eager to invest. For purposes of clarity it should be noted that the value of the $\mathrm{x}$ intercepts in this graph are not the same as in the chart representing the IRR. This is because the IRR does not take the discount rate, nor the inflation into consideration. It is merely the rate that renders the sum of all yearly cash flows to zero. On the contrary, the chart below depicts the NPV break even point that does take the discount rate and the inflation into account. 


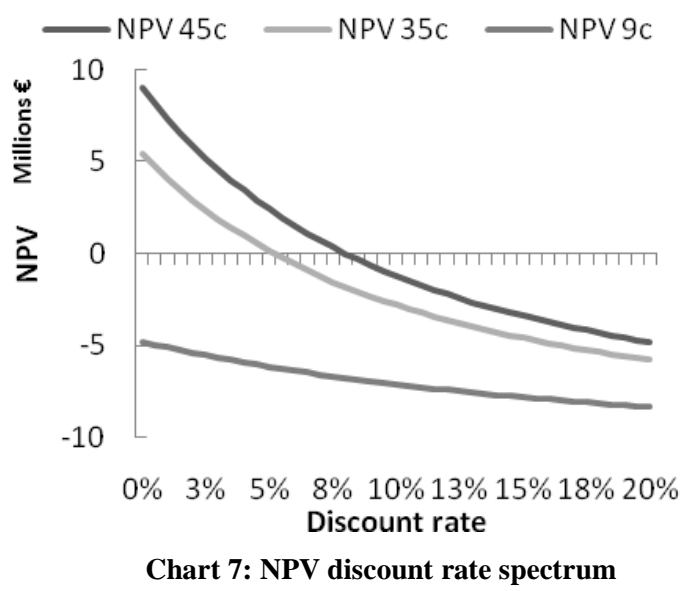

The higher the average yearly energy price inflation, the more profitable a PVGCS becomes see graph 8 and 9. The current situation does not attain a positive net present value because of the high discount rate. Also, it is noteworthy to mention the large slope of the 9c-curve in chart 9 . This can be explained by the bigger percentage of revenue originating from saved energy expenses when subsidy levels are reduced to $9 \mathrm{c}$. Furthermore the graphs support our assumption that the current environment is not yet ready for a drastic subsidy legislation change.

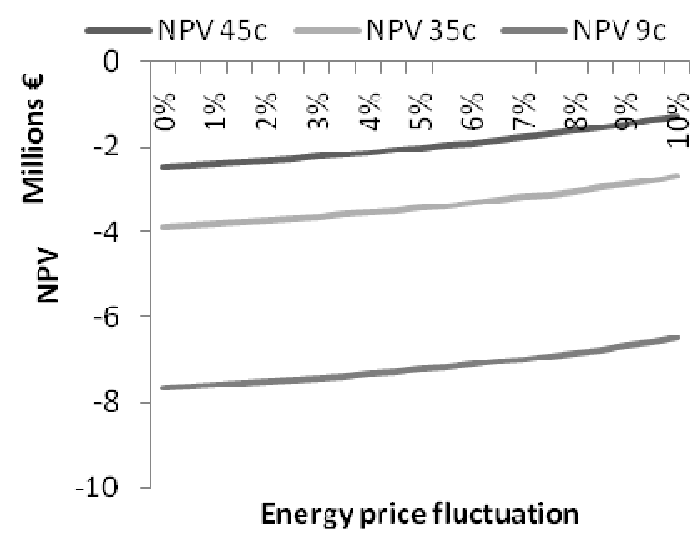

Chart 8: NPV energy price spectrum

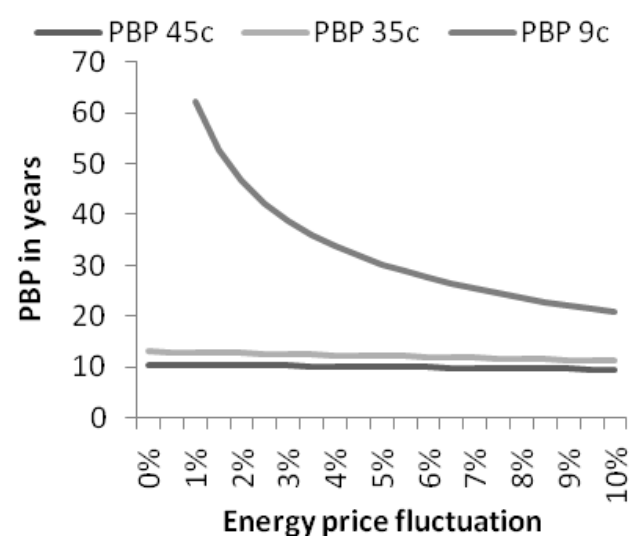

Chart 9: PBP energy price spectrum

\subsection{Results}

NPV, IRR and PBP indicate that the highest green current subsidy levels (45c or 35c/kWh) are needed to persuade companies in investing in a PVGCS given current prices. The current environment is not yet ready for a drastic green current subsidy legislation change to $9 \mathrm{c} / \mathrm{kWh}$. NPV also indicates that a discount rate of $10 \%$ is to high a demand even when the highest green current subsidies are in order. 


\section{Conclusion}

Using the cash flow projection method one can calculate the following classical evaluation criteria: net present value, internal rate of return, payback period, discounted payback period, profitability index, yield unit cost, yield unit return and breakeven turnkey cost. Their outcome makes it possible to answer the question of whether installing a PVGCS in Flanders is a responsible financial investment for companies.

To check for this, the model has been tested by means of a generic case study. Before presenting the results, the study's assumptions have to be addressed. Firstly, the model can only be put to use after a feasibility study has been executed. This study calculates the load the roof is able to tolerate. The roof hence determines the further development of the project. Secondly, the study assumes optimal functioning given contemporary characteristics of PV systems. Consequently, if the average productivity should rise the number of $\mathrm{kWh} / \mathrm{Wp}$.year that the system generates has to be adjusted accordingly. Thirdly, all parameters are fixed over a period of 20 years. Subsequently, no variability has been considered. The model is deterministic, not stochastic.

Bearing the above in mind, the following conclusion has been made. It is financially responsible to initiate a PVGCS project when loans are available and even when they are not. The positive IRRs, respectively $9.13 \%$ and $6.53 \%$, legitimate this statement. The difference between the IRRs can be solely attributed to financing costs, thus they can play an influential role on the return. Still, the PVGCS's viability needs some nuance. Companies might not consider these IRRs as sufficient proof. Indeed, calculating the NPVs using a $12 \%$ discount rate renders negative values and the payback period is longer than preferred by large companies. However, as noted in the sensitivity analysis revenues are mainly originating from subsidies and especially from green current certificates. As such, an almost risk free investment renders a positive return. On top of that a PVGCS will provide a company a positive green image, independence from energy suppliers and from carbon price fluctuations by diversifying their energy mix and long term energy cost control. The latter advantages have not been valuated, but they are definitely worth the effort. Still, if all mentioned benefits do not suffice, a company can ask a specialized company to take on the investment for them. This way the enterprise enjoys most benefits except subsidies, without taking on the burdens. This concurs with the frequently used path of handling non-core business: outsourcing.

To find the major drivers of solar power's financial attractiveness we applied a simple permutation and combination method to the $100 \%$ loan scenario. The most influential parameters are the initial investment cost, the discount rate, the energy price and the price of green current subsidies. Since the latter will face reduction in the future, it substantially influences the analysis. Hence, we wanted to estimate whether the current situation is ready for a green current subsidy legislation change. Consequently we gauged the current $45 \mathrm{c} / \mathrm{kWh}$ against the future 35 and $9 \mathrm{c} / \mathrm{kWh}$ scenario. Sensitivity analysis, using these parameters, allows the following conclusions to be drawn. NPV, IRR and PBP indicate that the highest green current subsidy levels are needed to persuade companies to invest in a PVGCS given current prices per Wp for an installation. NPV value supports the fact that discount rates higher than $10 \%$ are too high to demand, even for the highest green current subsidy levels. NPV and PBP also support our vision that the current environment is not yet ready for a drastic green current subsidy legislation change given energy price fluctuations. The same PBP-chart also shows 
that energy prices have a larger impact, if the green subsidy level drops. All the above take taxes into account, the YUR and YUC however do not. Still the same conclusion can be drawn from the fact that the $9 \mathrm{c}$-YUR does not have an intersection with the 9c-YUC.

Conclusion summary:

Yes, it is financially responsible to invest in a PVGCS for a Flemish company. The questions remains as to whether financial responsibility applies to other Belgian regions, whether notional interest deduction may be influential and whether it would be lucrative to produce more than is needed?

No, the current environment is not ready for a green current subsidy legislation change to $9 \mathrm{c} / \mathrm{kWh}$. Consequently this clears the path for further research and provides incentives for the industry to improve their technology and pricing. 


\section{References}

Alsema, E., \& Nieuwlaar, E. (2000). Energy viability of photovoltaic systems. Energy Policy , 28 (14), 999-1010.

Andersson, B., \& Jacobsson, S. (2000). Monitoring and assessing technology choice: the case of solar cells. Energy Policy, 28 (14), 1037-1049.

Awerbuch, S. (2000). Investing in photovoltaics: risk, accounting and the value of new technology. Enenergy Policy, 28 (14), 1023-1035.

Awerbuch, S. (1995). New economic cost perspectives for valuing renewables. In K. Böer, Advances in solar energy: An Annual Review of Research and Development (Vol. 10). Boulder: American Solar Energy Society.

Bernal-Agustín, J. L., \& Dufo-López, R. (2006). Economical and environmental analysis of grid connected photovoltaic systems in Spain. Renewable energy, 31 (8), 1107-1128.

Caamaño, E., \& Lorenzo, E. (1998). Modelling and financial analysis tools for PV grid-connected systems. Progress in Photovoltaics: Research and Applications , 4 (4), 295 - 305.

Chabot, B. (1998). From Costs to prices: Economic analysis of photovoltaic energy and services. Progress in photovoltaics: research and applications , 6 (1), 55-68.

Crevits, H. (2009, February 6). Vlaanderen legt grondslag voor groenestroombeleid tot 2020. Retrieved February 11, 2009, from www.vlaanderen.be: http://www.vlaanderen.be/servlet/Satellite?lang=NL\&pagename=nieuwsberichten/NB_Nieuwsbericht/ Nieuwsbericht\&cid=1233727058154

Deb Mondol, J., Yohanis, Y. G., \& Norton, B. (2009). Optimising the economic viability of gridconnected photovoltaic systems. Applied Energy, 86 (7-8), 985-999.

Demoor, W. (2008, September 19). Company visit VPLG. (S. Lizin, \& J.-F. Adam, Interviewers)

Derycke, M. (2007). Nieuwigheden vennootschapsbelasting. Mechelen: Kluwer.

Deutsche Gesellschaft für Sonnenenergie. (2005). Planning and Installing Photovoltaic Systems: A Guide for Installers, Architects and Engineers. London: Earthscan Publications.

Dorsman, A., Vanthienen, L., Keuleneer, L., Van Hulle, C., \& Gheysens, L. (2000). Financieel management. Antwerp: Standaard Uitgeverij.

Ecostream. (2006). Veel gestelde vragen. Retrieved February 3, 2009, from www.ecostream.be: http://www.ecostream.be/index.php?option=com_content\&task=view\&id=341\&Itemid=3618\&lang=n 1

Gabler, H. (2001). Grid-Connected Photovoltaics. Solar Energy, 70 (6), 455-456. 
Gitman, L. J. (2003). Principles of management finance: brief. Boston: Addison Wesley.

Groep Vaktijdschriften. (2008, January). Een krachtcentrale op het dak: de moeite waard? Intech elektro en ICT , pp. 1-4.

Hill, R., O'Keefe, P., \& Snape, C. (1995). The future of energy use. London: Earthscan Publications.

Jackson, T., \& Oliver, M. (2000). The viability of solar photovoltaics. Energy Policy , 28 (14), 983988.

Luyckx, L. (2008, October 1). Company visit Reynaers Aluminium. (J.-F. Adam, \& S. Lizin, Interviewers)

Menegaki, A. (2008). Valuation for renewable energy: A comparative review. Renewable and Sustainable Energy Reviews , 12 (9), 2422-2437.

Nofuentes, G., Aguilera, J., \& Muñoz, F. (2002). Tools for the profitability analysis of grid-connected photovoltaics. Progress in photovoltaics, 10 (8), 555-570.

Ondernemend Vlaanderen. (2009, January 21). Nieuwsberichten. Retrieved February 11, 2009, from Vlaamse overheid agentschap http:/ewblpublicatie.vlaanderen.be/servlet/ContentServer?c=Page\&pagename=Ondernemen/Page/MVG_CMS4_ VT_Special_Subnav\&cid=1199329319502

Van Campenhout, G. (2008). Investeringsbeleid. Brussels, Belgium.

Vlaams Energieagentschap. (2007, February). Verhoogde investeringsaftrek voor energiebesparende investeringen. Retrieved September 9, 2008, from www.energiesparen.be: http://www.energiesparen.be/subsidies/subsidieregel_detail?id=1831\&verstr=769\&doelgroep=2

Vlaamse Overheid: Agentschap Economie. (2007, October 1). Call Ecologiepremie: Algemene Informatie. Retrieved September 9, 2008, from vlaanderen.be/ecologiepremie: http://ewblpublicatie.vlaanderen.be/Uploads/EP-call\%20Algemene\%20\%20infoteksten\%2020071001_def,0.pdf

Vlaamse Reguleringsinstantie voor de Elektriciteits- en Gasmarkt. (sd). Groenestroomproducenten De aanvraag - Hoe aanvragen? Retrieved September 9

Vlaamse Reguleringsinstantie voor de Elektriciteits- en Gasmarkt. (sd). Grote Ondernemingen Groene stroom - Groene stroom produceren via zonnepanelen - Technische vereisten. Retrieved March 10, 2009, from www.vreg.be: http://www.vreg.be/nl/05_professioneel/04_groteondernemingen/05_groenestroom/03_productie/04_t echnisch.asp

Yun Seng, L., Lalchand, G., \& Mak Sow Lin, G. (2008). Economical, environmental and technical analysis of building integrated photovoltaic systems in Malaysia. Energy Policy, 36 (6), 2130-2142.

Zahedi, A. (2009). Development of an economical model to determine an appropriate feed-in tariff for grid-connected solar PV electricity in all states of Australia. Renewable Sustainable Energy Reviews , $13(4), 871-878$. 


\section{Appendix: Parameters case study}

\begin{tabular}{|c|c|c|}
\hline Parameter & Value & Motivation \\
\hline Discount rate & $12 \%$ & $\begin{array}{l}\text { Discount rate of an existing exemplary Flemish } \\
\text { company. }\end{array}$ \\
\hline Yearly monetary inflation rate & $2 \%$ & $\begin{array}{l}\text { Average inflation over a period of } 1998-2008 \text { in } \\
\text { Belgium calculated using data from Statbel } \\
\text { Indicators. }\end{array}$ \\
\hline Electricity cost & $\begin{array}{l}0.095 \\
€ / \mathrm{kWh}\end{array}$ & $\begin{array}{l}\text { Electricity cost of an existing exemplary Flemish } \\
\text { company. }\end{array}$ \\
\hline Yearly energy inflation rate & $3 \%$ & $\begin{array}{l}\text { Most suppliers use at least 5\%. This would } \\
\text { represent an enormous rise over a period of } 20 \\
\text { years. Given the average rise of energy prices in } \\
\text { Belgium for companies over the last available } 20 \\
\text { years of information we have chosen to lower the } \\
\text { yearly energy inflation rate to } 3 \% \text { by averaging the } \\
\text { last obtainable data for electricity prices } \\
\text { companies according to Statbel and the electricity } \\
\text { price evolution of an existing exemplary Flemish } \\
\text { company. As such we take on a conservative } \\
\text { position. }\end{array}$ \\
\hline $\begin{array}{l}\text { Yearly System performance } \\
\text { deterioration rate }\end{array}$ & $1 \%$ & $\begin{array}{l}\text { According to the performance warranty on solar } \\
\text { modules. }\end{array}$ \\
\hline Lending rate & $4.75 \%$ & Lending rate of an existing exemplary company. \\
\hline Lending payback period & 10 years & $\begin{array}{l}\text { Consequential to the degressive amortization } \\
\text { period. It is not likely that the Belgian tax } \\
\text { collector will tolerate amortization before the asset } \\
\text { is fully paid back. }\end{array}$ \\
\hline Corporate tax rate & $34 \%$ & Belgian tax rate for large companies. \\
\hline Degressive amortization period & 10 years & $\begin{array}{l}\text { No existing legislation exists. A period of time can } \\
\text { be agreed upon with the tax officer. (Derycke, } \\
\text { 2007) }\end{array}$ \\
\hline Green current certificates & $45 \mathrm{c} / \mathrm{kWh}$ & (Crevits, 2009) \\
\hline $\begin{array}{l}\text { Elevated investment deduction } \\
\text { percentage }\end{array}$ & $13.5 \%$ & (Vlaams Energieagentschap, 2007) \\
\hline $\begin{array}{l}\text { Percentage of essential parts in } \\
\text { initial investment }\end{array}$ & $90 \%$ & $\begin{array}{l}\text { According to real offering of a solar installer. } \\
\text { (Demoor, 2008) }\end{array}$ \\
\hline $\begin{array}{l}\text { Percentage of inverters in initial } \\
\text { investment }\end{array}$ & $20 \%$ & $\begin{array}{l}\text { According to real offering of a solar installer. } \\
\text { (Demoor, 2008) }\end{array}$ \\
\hline $\begin{array}{l}\text { Percentage of inverters replaced } \\
\text { in midlife of the PVGCS }\end{array}$ & $100 \%$ & (Yun Seng, Lalchand, \& Mak Sow Lin, 2008) \\
\hline
\end{tabular}




\begin{tabular}{|l|c|l|}
\hline $\begin{array}{l}\text { Percentage of panels replaced } \\
\text { every year except the first 2 } \\
\text { years }\end{array}$ & $0.1 \%$ & $\begin{array}{l}\text { A very small percentage according to an expert in } \\
\text { the field of PV systems. (Luyckx, 2008) }\end{array}$ \\
\hline Insurance costs & $0 €$ & $\begin{array}{l}\text { Assuming that the company's current insurance } \\
\text { covers the possible risks. }\end{array}$ \\
\hline Maintenance costs & $4,000 € / y e a r$ & $\begin{array}{l}\text { Inspired by Zahedi (2009), compared to initial } \\
\text { investment outlay. }\end{array}$ \\
\hline
\end{tabular}

